\title{
Sustainable Application of Livestock Water Footprints in Different Beef Production Systems of South Africa
}

\author{
Ayanda M. Ngxumeshe * $\mathbb{D}$, Motshekwe Ratsaka, Bohani Mtileni and Khathutshelo Nephawe \\ Tshwane University of Technology, Faculty of Science, Department of Animal Sciences, Staatsartilerie Road, \\ Pretoria Campus, Private Bag X680, Pretoria 0001, South Africa; RatsakaMM@tut.ac.za (M.R.); \\ MtileniB@tut.ac.za (B.M.); NephaweKA@tut.ac.za (K.N.) \\ * Correspondence: NgxumesheAM@tut.ac.za; Tel.: +27-12-382-4898
}

Received: 1 October 2020; Accepted: 16 November 2020; Published: 27 November 2020

check for updates

\begin{abstract}
There is an increase in requirement and competition for water, while water resources are decreasing at an accelerating rate. Agriculture is the biggest consumer of water and therefore has the largest water footprint, which is not yet known. The largest portion is acknowledged to be for producing animal products. Water footprints account for the amounts of water used to produce a commodity for consumption, measured along the commodity life cycle. Water withdrawals from surface and groundwater are accounted for when assessing the water footprint. The three identified major determinants of a water footprint of meat include feed conversion efficiency (FCE), feed composition, and feed origin, with the first two being influenced greatly by the animal production system. In South Africa (SA), the two distinct production systems are the intensive and extensive production systems. Intensifying beef animals improves FCE due to faster growths per $\mathrm{kg}$ feed consumed, reduced activity, and therefore reduced water footprint. Beef cattle in the extensive system consume a large component of roughages, while the intensive system has a high concentrate to roughage ratio. This theoretically increases the water footprint in the intensive system. The literature indicates large amounts of volumetric water footprint indicators of boneless beef in SA. Water footprint assessment is critical for enabling consumers to make well-informed and sound decisions when considering changes in their behavior due to the effect this has on social, economic, and environmental wellbeing. This paper aims to postulate the various issues associated with water usage in beef production. These include factors affecting the water footprint of beef production and the effects it has on various aspects of both the environment and social wellbeing. It further explores the various methods to assess the water footprint of a product.
\end{abstract}

Keywords: Water use; production system; animal feed; drinking water

\section{Introduction}

Incidents of drought resulting from climate change have severely impacted water-available resources [1]. The anticipated growth in the world population assumes intensification of water-availability concerns as food demand escalates, particularly the demand for food of animal origin. This results in a shift from extensive animal production towards semi- and intensive production systems in an attempt to meet this escalating demand [2]. The expected environmental impacts of increased consumption of animal products [3-6], and the pros and cons of intensive and extensive production systems $[7,8]$ have been researched extensively. There is an undeniable impact on and increase in pressure exerted on water resources due to the intensification of animal production systems.

There are several other factors associated with this increase in water consumption from the intensive production system, such as low efficiency of rations [9]. Animals kept under the traditional extensive system generally utilize land that would not be suitable for either human settlement or other 
crop production purposes. Therefore, they largely utilize the green water which forms part of the water footprint assimilated in pastures [10]. A water footprint is an indicator of the degree of sustainability in which freshwater is drawn to maintain economic activities, such as food production [11]. It provides information on two facets of water use: (1) the total amounts of freshwater utilized to produce the required quantities of food product and to deliver it to the end-consumer, measured along the entire supply chain of a commodity, and (2) the degree of sustainability with which freshwater was used. The volume of water used to produce the required quantities of a food product-for example, the liters of water used to produce $1 \mathrm{~kg}$ of beef-is referred to as the volumetric water footprint indicator [11-13].

This paper aims to postulate the various issues associated with water usage in beef production. These include contributing factors to the water footprint of beef production and the effects it has on various aspects of both the environment and social wellbeing. This paper will further explore the various methods for assessing the water footprint of a product.

\section{The South African Beef Industry}

Beef production has a fundamental role in socioeconomic status of South Africa (SA). The Department of Agriculture Forestry and Fisheries (DAFF) [14] reported that, of the total cattle herds in SA, $80 \%$ contribution is from beef animals while the other $20 \%$ is made by dairy herds. It is the second fastest growing industry after the poultry industry in the agricultural sector of SA. This growth is driven by escalating demand for meat as the human population grows rapidly. The other drivers of this increasing demand include urbanization as well as improving economic status of many households, which enables them to afford beef products. This tremendous increase in beef consumption was observed in the last decade and bares a large contribution in spawning revenue for the country. A gross value increase of $135 \%$ was observed during this period from R13 billion in 2006/07 to R30.6 billion in 2015/16, with an average of R19 billion per annum [14].

\section{Water Footprint of Beef Production}

WF indicates how water utilization by livestock production systems impact water resources [11]. It estimates the amount of water utilized to produce a kilogram of meat. This water is measured along the production lifespan from input production till the stage, where the final product reaches the consumer [11,12]. WF is mapped into green, blue, and grey categories. Green and blue water are both involved in food production, and grey water is involved in diluting polluted water.

\subsection{Green Water Footprint}

Green water footprint sustains global rain-fed agriculture, ecosystems, and ecosystem services. This is the water that infiltrates into the soil. It has both a productive role as transpiration and a non-productive role as evaporation in the biosphere $[11,12,15]$. Green water has a direct correspondence to precipitation pattern, soil profile, as well as climatic conditions. It is accessible only to plants and cannot be directly manipulated by human management.

Green water reaching the soil surface is used by plants; recharges groundwater by filtration; or runs off towards surface water, lakes, and rivers. The water is also used for human activities from lakes, rivers, and groundwater. Some of the water is lost through evapotranspiration. Animals consume green water by feeding on the grasses. To get a measure of the green water, the amount of feed and the amount of water in the feed consumed by animals must be quantified [11]. It can therefore be concluded that green water is roughly comparative to rainfall and crop yield.

\subsection{Blue Water Footprint}

Blue water footprint has a variety of uses. These include irrigation agriculture, and industrial and domestic needs of society. These are sectors that compete for blue water supply, thereby exerting pressure on this limited resource [16]. Blue water use has a higher opportunity cost in comparison to green water use. A $40 \%$ contribution to food production from irrigated agriculture was reported [17]. 
However, due to population increase projections by 2050 [18] that will result in increased demand for food, irrigation agriculture is expected to rise drastically to sustain these demands as will dietary shifts toward meat consumption due to income growth [19].

\subsection{Grey Water Footprint}

Grey water is calculated as the volume of water required to reduce pollutants to acceptable levels. This would enable the quality of ambient water to remain above defined water-quality standards [10]. According to Verlicchi and Grillini [19], nitrogenous fertilizers in SA have the highest impact on water quality. They reported that only nitrites exceeded the acceptable limits. However, this may be affected by the type of fertilizers used in specific regions. Seasonal variations may also be observed [20]. Therefore, although nitrates are commonly considered of primary concern, the type of fertilizer and growing season need to be considered for more realistic grey water assessment.

\section{Effects of Water Footprint}

\subsection{Water Scarcity}

In 2016, an estimated four billion people globally were faced with severe water scarcity [21]. This water scarcity is expected to intensify due to increases in population [22]. The sharp increase has been observed since the 1960s [23]. Porkka et al. [24] alluded that this sharp rise is due to the expansion of agricultural land to meet the escalating demands for food. Water scarcity is the condition presented by freshwater demands surpassing availability. Blue water scarcity relates to the direct insufficiency of water in rivers and aquifers $[25,26]$. This is a major concern in the agricultural sector due to its reliance to a large extent on large amounts of water. South African river basins are already faced with moderate or severe water scarcity in most months of each year (Figure 1) [15,27]. Fodder crops contribute the most to the blue water footprint, except for the Komati and Maputo river basins that sustain mostly the sugarcane plantations. This is a serious concern considering the predicted increases in world population that comes with escalated demands for more food. Pressure will intensify on agriculture to significantly increase its production to meet this demand $[28,29]$. There are expected production and consumption increases of $2.5-4 \%$ annually in developing countries [30].

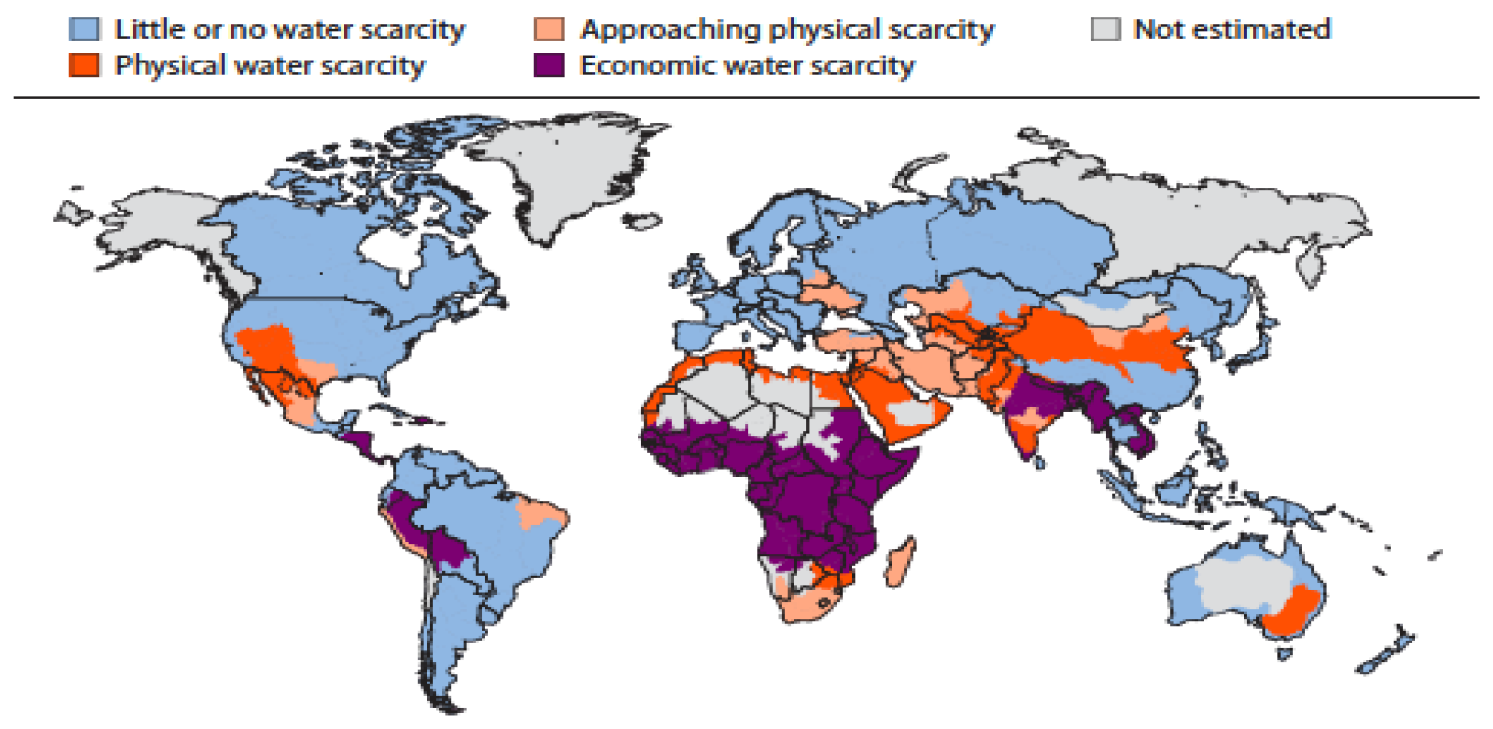

Figure 1. Map of water scarcity [15]. 


\subsection{Water Quality}

Water quality is declining at a significant rate as seepage from mines, sewerage systems, and other sources are discharged casually due to ineffective effluent disposal policies. In the agriculture industry, effluent seepage is from abattoirs and dairy processing plants, which poses a major source of pollution to ground and surface water resources [31] and endanger the already stressed water supplies. For cattle fodder production, intensive system uses nitrogen and phosphorus fertilizers on both crops used for cattle feeds and cultivated pastures to increase yields [32]. These fertilizers together with the use of pesticides contribute to the continuous degradation of water quality. The nutrient load in water encourages the growth of algae that negatively affects the drinking water quality and spoils recreational areas. The accumulation of these toxic compounds in water limits access to clean water for human consumption. They also contaminate and threaten the aquatic food web as they may accumulate in fishes for human consumption. In the long run, there could be a decline in some indigenous fish species and a change or imbalance in aquatic species diversity.

\subsection{Environmental Effects}

The amount of water required in livestock production systems has been well recognized; however, these amounts differ significantly with varying environmental conditions [33,34]. For example, heat stress may considerably increase the water requirements of various livestock species including beef cattle, while cold stress may decrease water intake. Environmental factors that vary momentously during hot and cold seasons include temperature, relative humidity, wind speed, solar radiation, and precipitation [33]. Their variations or combination of environments may affect the water footprint significantly.

An increase in relative humidity reduces evaporative cooling effects, which may result in cattle drinking more water for body temperature regulation purposes. Wind speed contributes to evaporative cooling, which may increase the water requirements of cattle to maintain homeostasis. During cold seasons, it may result in cold stress that will significantly reduce water intake [34]. Solar radiation increases body temperature and thereafter water intake. Hide color also plays an important role because cattle with different hide colors absorb solar radiation at different rates. Precipitation reduces water intake [35].

\subsection{Social Well-Being}

There are water-related basic human needs to be met continuously to deem the water footprint socially sustainable. Among these are basic needs for safe drinking water, cleaning and cooking services [36], as well as water for food production to ensure food security for all. Water availability affects mostly women, due to the responsibility imposed on them to collect water in the majority of developing countries [37,38]. Water also affects human health. Sartori et al. [37] reported that $80 \%$ of illnesses in developing countries are the result of poor water quality and hygienic standards, while Hoekstra et al. [11] identified rules of fairness that include freshwater availability. The first rule affects employment, particularly in fisheries where downstream fisheries might be affected by pollution from upstream fisheries. The second rule is the use of water as a public good whereby small-scale farmers neighboring commercial farms may have limited access to freshwater due to big wells dug by commercial farms for irrigation.

\subsection{Economic Opportunity Cost}

Utilization of water for meat production should outweigh the costs associated with its water footprint. Hoekstra et al. [11] described an economically unsustainable water footprint as the price of water being below its economic cost. Economic water productivity is used to measure the income generated per cubic meter of water used [10,39]. Such studies have been published on the dairy value chain in SA in 2017 [40]. These have taken into account economic water productivity for both 
milk and fodder crops. Their findings, as presented in Table 1, indicate economic water productivity measures of the main foodstuffs used in South African dairy feeds. These results give an indication of what foodstuff has lower economic water productivity (for example, maize silage in Table 1) to assist the farmer's decision on the continued use of the foodstuff particularly when its impact is minor on production, as observed on the percentage contribution to milk production. The results of Owusu-Skyere et al. [40] shows that economic water productivity of different feedstuff is not directly related to other parameters of economic importance such as product value added and product yield. Ololade [32] indicated that only blue water resources are accounted for in economic water productivity assessments because only blue water resources are considered of economic importance as the green water resources are not properly recognized.

Table 1. Value addition and economic water productivity of main foodstuffs [40].

\begin{tabular}{|c|c|c|c|c|}
\hline Feedstuff & $\begin{array}{l}\text { Marginal Water } \\
\text { Productivities } \\
\left(\mathrm{Kg} / \mathrm{m}^{3}\right)\end{array}$ & $\begin{array}{l}\% \text { Contribution } \\
\text { to Milk Yield }\end{array}$ & $\begin{array}{l}\text { Value Added } \\
\text { (Rand/Kg) }\end{array}$ & $\begin{array}{c}\text { Economic Water } \\
\text { Productivities } \\
\left(\text { Rand } / \mathrm{m}^{3}\right)\end{array}$ \\
\hline Lucerne hay & 3.64 & 16.04 & 1.88 & 6.84 \\
\hline Oats silage & 3.84 & 3.99 & 1.37 & 5.22 \\
\hline Sorghum silage & 5.22 & 9.80 & 1.67 & 8.72 \\
\hline Maize silage & 4.91 & 14.78 & 1.66 & 3.25 \\
\hline Maize meal & 1.53 & 28.42 & 4.39 & 6.71 \\
\hline HPC & 0.93 & 18.47 & 6.91 & 6.43 \\
\hline
\end{tabular}

HPC $=$ High protein concentrate.

\section{Factors Affecting Water Footprint}

The predisposing factors of water usage in beef production are beef cattle breed, animal activity, diet type, feed consumption, water quality and temperature, as well as the ambient environment [41]. Fodder production makes up the largest amount of water used in beef production. This is increasing rapidly at a global scale to supply the demands of the growing population [42].

\subsection{Types of Livestock Farming Systems}

There are two distinct types of production systems identified in SA: the extensive and intensive production systems. Extensive production system predominantly characterizes beef cattle production systems in SA, and are widely based on natural pastures (rangelands) [43].

\subsubsection{Extensive Production System}

Extensive beef production system utilizes rainwater with no competition with runoff to water bodies like rivers, dams, and underground aquifers for industrial and domestic consumption. The authors of [12] calculated that agriculture accounts for $86 \%$ of global water consumption. However, crop production and natural pastures (rangelands) use only the water stored in the soil after precipitation. This water is referred to as green water because it is only utilized by green vegetation growing in the soil. This water is not available for use for any other purpose. Extensive beef production systems rely on the green vegetation as a source of food that utilizes only green water.

Furthermore, extensive beef production is generally practiced on lands that cannot sustain crop production due to scarce rainfall and poor quality of soils [31,44]. In this production system, it is generally excluded when calculating water consumption. If not utilized for livestock or game, natural pastures would otherwise be unproductive. Its productivity is only toward beef and dairy production on extensive production systems grazing on natural pastures. An example of the KwaZulu Natal and Coastal Eastern Cape areas of South Africa. These extensive production systems are critically 
accountable for food security in such areas, which dominate almost all less developed countries. Natural pastures in these areas do not use "blue" water [45,46].

\subsubsection{Intensive Production System}

Intensive production systems are characterized by high stocking densities per hectare. They are described as comparatively high productivity systems that are fairly efficient. Intensive systems heavily relies on total mixed rations (TMRs) with less than $10 \%$ of feed ingredients produced at the farm itself $[31,43,44]$. Contrary to semi-extensive and extensive production systems, intensive feedlot systems are practically committed to producing at an accelerated rate in response to the increasing demand for beef in urban areas. Feedlot cattle are largely dependent on high energy diets that are composed of grains not produced locally on-farms. These high energy diets are designed to speed up daily weight gains. The feedlot systems are big operations that are vertically integrated and fully industrialized. These production systems are therefore characterized by highly standardized technology and practices than semi-extensive and extensive production systems. However, the intensive feedlot systems are often linked to these semi-extensive or extensive production systems where they obtain their animals (weaner calves and yearlings) to fatten them till slaughter weight.

Globally, feedlot systems are currently holding about $2 \%$ of the cattle population with a contribution of about $7 \%$ to beef production (including animals sourced from semi-extensive and extensive production systems) (Figure 2) which means there will also be an increase in water requirements under such systems. In developed countries like the United States and Canada, feedlot systems are well advanced while in other countries like Asia and the African countries are growing at an accelerated rate in response to the mounting demand for beef [47].

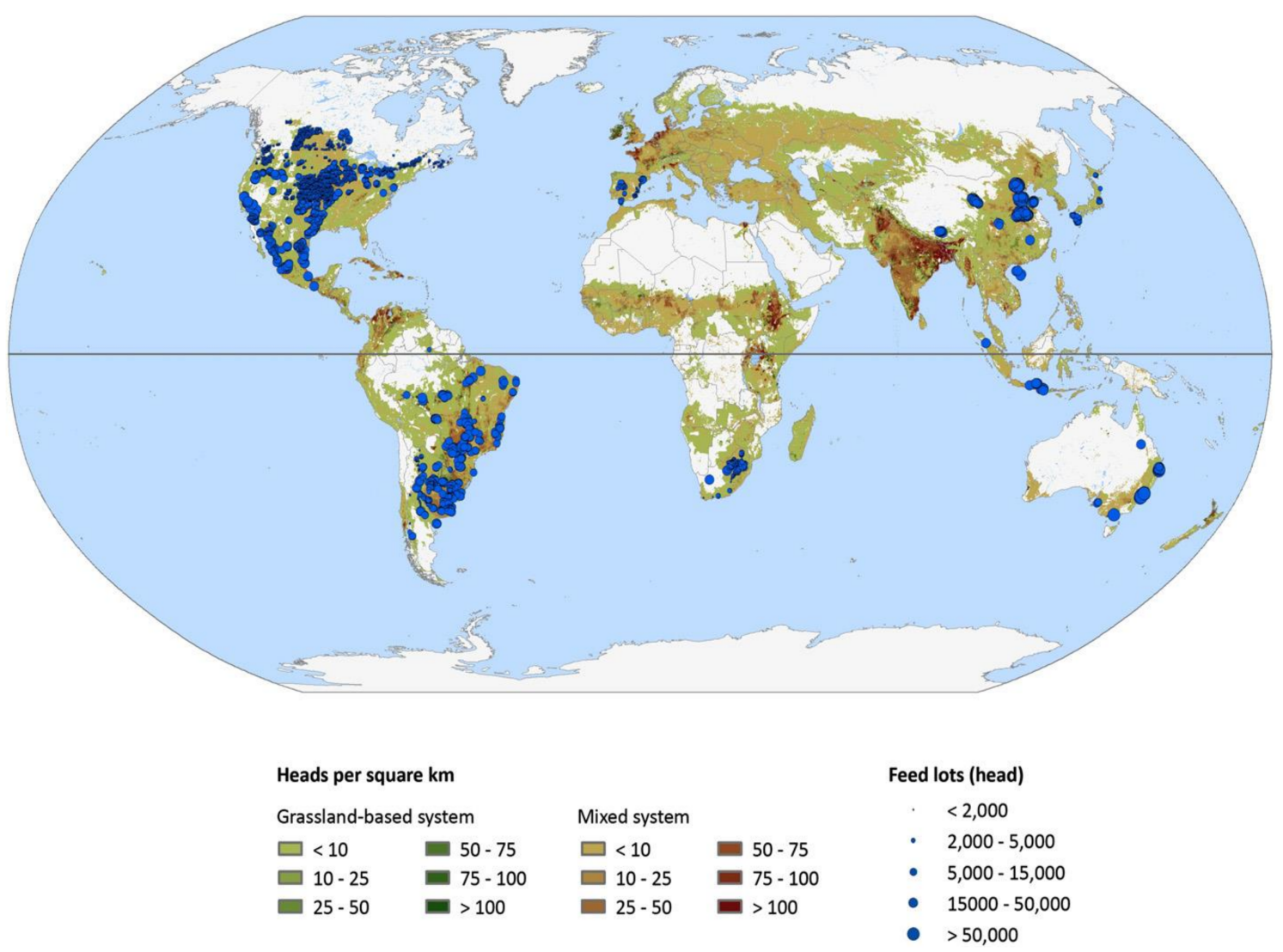

Figure 2. Estimated cattle population in grazing, mixed, and feedlot systems. Source: [47]. 
Feedlot systems are well regulated to produce uniform carcasses as required in the retail sphere. They use in abundance the crop products as well as by-products like the oilcake meals and Dried Distillers Grains with Solubles (DDGS). Their use of these natural resources is fairly efficient as depicted by their faster growth rates and efficient feed conversion ratios [3,48], although in comparison are usually poorer than the intensive poultry and pig operations. Nevertheless, they are linked to high bearings on plummeting water supplies and air quality, mostly due to the geographical concentration of production units [49]. Mare and Jordaan [50], found that water use in the feedlot will differ according to cattle breed and diet type. They also found that green water has a significantly high percentage contribution of water footprint.

\subsection{Feed Composition}

The amount of water (blue) withdrawn from rivers, lakes, and groundwater resources for food production at a global scale is enormous [10,42]. This also refers to the green water evaporated through vegetation (both crops and grazing plants) [51]. The beef production industry utilizes green and blue water through water extractions for irrigation of fodder crops as well as establishment of pastures and conversion of land use to beef farming operations that affect the shifts in water resource utilization as a consequence of changes in land use [42].

It is significantly important to understand that land used for livestock production is commonly unsuitable for other land use purposes like human settlements and/or crop production [29]. Steinfeld et al. [29] further argued that, where these lands are not utilized for livestock production, they would otherwise be redundant. Therefore, green water associated with their use is somewhat irrelevant to be accounted for in production. However, Pimentel $[52,53]$ had earlier highlighted the importance of giving due consideration to evapotranspiration when calculating water flows and usage in agriculture at large. Falkenmark and Rockström [28] further contribute to the disagreement by defending accounting for the evaporation from pasture lands only from vegetation component actually consumed by livestock while not accounting for the rest in terms of water requirement for livestock.

\subsection{Feed Origin}

Beef production in South Africa is practiced under extensive and intensive production systems. The extensive system, which is the major contributor to beef production in SA [31,43,44], feeds predominantly on rain-fed natural rangelands. The contrasting factor in the intensive production system is that their food predominantly originates from cultivated fodder crops that form the total mixed rations for feedlot animals and cultivated pastures that are fertilized and irrigated to encourage faster pasture development and basal cover. Fodder crops are the major consumers of blue water from the majority of the river basins in South Africa, with Gamka River in the Western Cape utilizing a maximum of $62 \%$ [27]. The impact that irrigated foodstuffs will have on the water footprint depends on the time of the year when it is planted and irrigated. For instance, feedstuffs planted in summer months may theoretically have no impact on water scarcity. Table 2 illustrates South Africa is having severe water scarcity in most months of the year [27]. This table shows that the biggest river basins in South Africa (Limpopo, Great Fish, Doring, and Great Kei) are facing severe water scarcity and depletion for most of the year. This is cause for concern and therefore warrants blue water accountability to raise awareness and to develop water conservation strategies. 
Table 2. Major river basins in South Africa (SA), their respective population, the number of months that a basin faces blue-water scarcity, and products with a significant contribution to WFblue [27].

\begin{tabular}{|c|c|c|c|c|c|}
\hline \multirow[t]{2}{*}{ River basin } & \multirow[t]{2}{*}{ Population } & \multicolumn{3}{|c|}{$\begin{array}{l}\text { Number of Months per Year that A } \\
\text { Basin Faces Blue-Water Scarcity }\end{array}$} & \multirow{2}{*}{$\begin{array}{c}\text { Products with A Significant } \\
\text { Contribution }(\geq 3 \%) \text { to WFblue in } \\
\text { the Basin }\end{array}$} \\
\hline & & Moderate & Significant & Severe & \\
\hline Limpopo & $15,637,400$ & 2 & 0 & 5 & $\begin{array}{c}\text { Fodder crops-31\%, sugarcane- }-11 \% \text {, } \\
\text { seed cotton- } 11 \% \text {, wheat- } 6 \% \text {, } \\
\text { domestic-5\%, maize- } 4 \%, \\
\text { bananas-3\% }\end{array}$ \\
\hline Orange & $12,665,700$ & 2 & 1 & 3 & $\begin{array}{c}\text { Fodder crops-36\%, wheat- }-11 \% \text {, } \\
\text { maize- } 8 \% \text {, sugarcane }-7 \% \text {, } \\
\text { domestic- } 5 \% \text {, potatoes-3\%, } \\
\text { grapes-3\% }\end{array}$ \\
\hline Komati & $2,416,140$ & 1 & 0 & 3 & $\begin{array}{c}\text { Sugarcane }-33 \% \text {, fodder crops-28\%, } \\
\text { maize }-5 \% \text {, domestic-5\%, seed } \\
\text { cotton- } \% \text {, apples- } 4 \%, \\
\text { bananas-3\% }\end{array}$ \\
\hline Maputo & $1,264,770$ & 1 & 0 & 3 & $\begin{array}{c}\text { Sugarcane }-81 \%, \text { fodder crops }-6 \% \\
\text { domestic }-4 \%\end{array}$ \\
\hline Tugela & $1,784,420$ & 2 & 0 & 3 & $\begin{array}{c}\text { Fodder crops-28\%, maize- } 16 \% \text {, } \\
\text { grapes- } 12 \% \text {, sugarcane- } 6 \% \text {, } \\
\text { apple- } 5 \% \text {, wheat }-4 \% \text {, } \\
\text { bananas- } 4 \% \text {, domestic- } 4 \% \text {, } \\
\text { pears-3\% }\end{array}$ \\
\hline Great Fish & 299,461 & 0 & 0 & 12 & $\begin{array}{c}\text { Fodder crops- }-49 \% \text {, sugarcane- }-10 \% \text {, } \\
\text { apples- } 6 \% \text {, bananas }-5 \%, \\
\text { maize }-3 \% \text {, pears }-3 \%\end{array}$ \\
\hline Doring & 167,084 & 0 & 1 & 7 & $\begin{array}{c}\text { Fodder crops- }-48 \% \text {, wheat }-11 \% \text {, } \\
\text { sugarcane- } 11 \% \text {, grapes-11\%, } \\
\text { potatoes-3\% }\end{array}$ \\
\hline Gamka & 278,648 & 2 & 1 & 1 & $\begin{array}{c}\text { Fodder crops- }-62 \% \text {, sugarcane- }-10 \% \text {, } \\
\text { grapes-7\%, wheat }-6 \%\end{array}$ \\
\hline Great Kei & 873,587 & 0 & 1 & 11 & $\begin{array}{c}\text { Fodder crops- } 53 \% \text {, domestic }-10 \% \\
\text { sugarcane-9\%, apples-4\%, } \\
\text { bananas-3\% }\end{array}$ \\
\hline
\end{tabular}

\subsection{Ambient Environment}

The main environmental factors affecting animal water intake are ambient temperature, humidity, and wind velocity [32,54]. High ambient temperatures increase water and ion losses of ruminants and thereby increase water requirements [55]. This agrees with Scholtz et al. [44], who reported increased perspiration and water intake due to high temperatures and solar radiation. Meyer et al. [56] reported a $0.5 \mathrm{~kg}$ drinking water intake with every degree Celsius increase in ambient temperature (Table 3). However, the rise in humidity decreases the drinking water demand.

Table 3. The mean, S.D., minimum and maximum values for the variables and the correlation coefficients between water intake and the other variables (edited from [56]).

\begin{tabular}{lccccc}
\hline & Mean & S.D. & Min & Max & $r$ \\
\hline Average ambient temperature $\left({ }^{\circ} \mathrm{C}\right)$ & 11.2 & 6.9 & -8.6 & 26.0 & $0.295^{*}$ \\
Maximum ambient temperature $\left({ }^{\circ} \mathrm{C}\right)$ & 15.0 & 8.1 & -5.9 & 33.8 & $0.282^{*}$ \\
Relative humidity $(\%)$ & 79.8 & 11.9 & 48.0 & 100.0 & $-0.092 *$ \\
Water intake (kg/day) & 17.8 & 6.7 & 0 & 78.7 & \\
\hline & $* p<0.001$ & & &
\end{tabular}




\section{Water Use Efficiency in Beef Cattle}

Water is the most vital nutrient required in the animal body. It constitutes above $70 \%$ of the animal live weight [57]. To maintain this enormous pool of water, animals acquire water through drinking, water from the food consumed, and metabolic water. However, not all this water is assimilated in the animal body. Some of the water is eliminated through urine, feces, respiration, and perspiration $[55,56]$. Therefore, water use efficiency is defined as the ratio of the water assimilated in the animal body to the actual water consumed. Figure 3 illustrates the sources of water utilized by beef cattle as well as excretion flows.

\section{Water inputs}

\section{Water outputs}

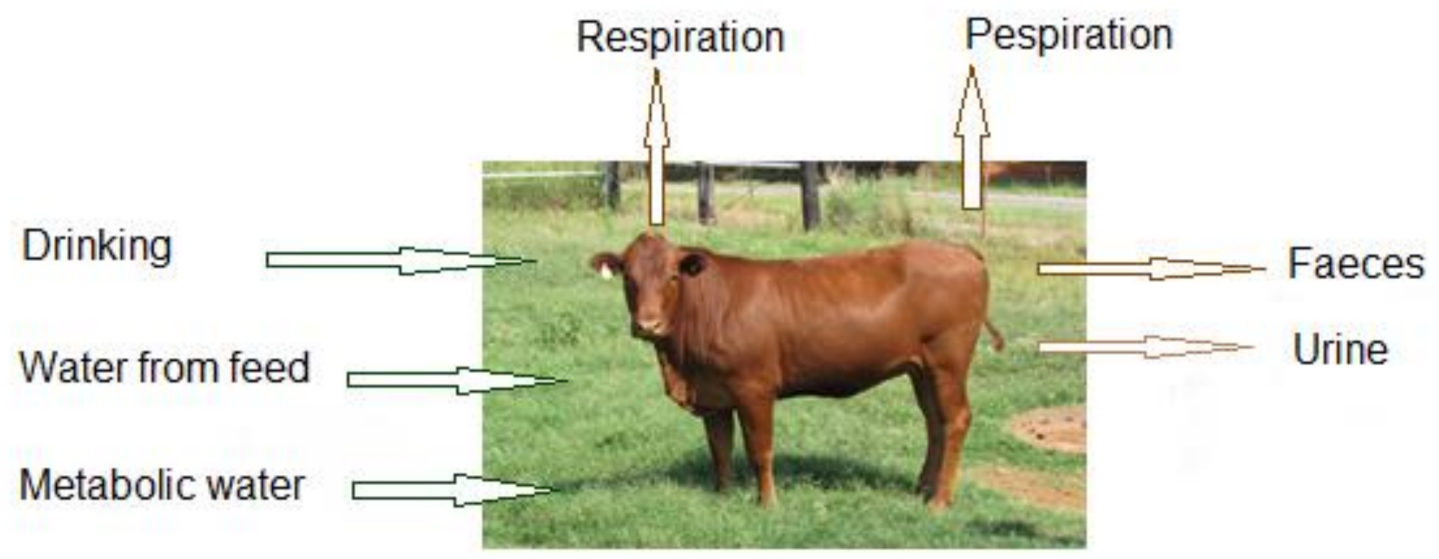

Figure 3. Water intake and excretion flows in beef cattle (Own illustration deduced from [56].

\section{Methods for Estimating Water Footprint}

There are several approaches that can be employed to assess water footprint of a product. Each details explicit stages with emphasis on water resource management and impact assessment $[16,38]$. Hoekstra et al. [11] have outlined steps that measure the volume of fresh water that can be compared to total viable bounds within a limit to determine water scarcity on their water footprint network manual. There is also a Life Cycle Assessment (LCA) that is used to evaluate the potential environmental impacts of water utilization following the ISO 14046 standard.

\subsection{Water Footprint Network}

Water footprint assessment (WFA) approach considers freshwater resource allocation using a four-stage method comprising setting goals and scope, water footprint accounting, sustainability assessment, and response formulation $[10,11,38,58]$. The accounting stage comprises quantification and mapping of freshwater use with three distinct types of water use: blue, grey and green water footprints. It is mainly intended to support better water management, including its use and allocation, and has played an important role in the awareness raising of water issues in the past decade.

\subsection{Life Cycle Assessment}

The LCA approach intends to quantify possible environmental affects spawned by human activity on extensive range of environmental matters (climate change, air quality, land utilization, etc.) [16]. Water utilization is among the possible effects. LCA therefore includes possible affects from depriving human population and biomes of water supplies as well as specific possible affects from the emitted contaminants affecting water through different environmental impact pathways and indicators (mainly eutrophication, acidification, and toxicity to humans and ecosystems). The LCA methodology includes 
four phases: goal and scope, inventory accounting, impact assessment, and interpretation [16,59]. Quantitative impact indicators are at the core of the impact assessment phase.

\subsection{Net Water Footprint}

Vahnm and Bidoglio [60 cited by 59] had identified limitations with the water footprint network (WFTN) of Zhuo et al. [16]. Atzori et al. [59] identified limitations with the life cycle assessment (LCA) due to its focus on only blue water [16,59]. They developed a new concept of generic framework [16], the net water footprint $\left(\mathrm{WFT}_{\text {net }}\right)$, or the generic framework as illustrated in Figure 4 [59-61], with both the WFA and LCA playing complementary roles. This method was used by Pacetti et al. [62], who also aimed to take advantage of the integration of these approaches to achieve a comprehensive assessment as it assessed both water use along with environmental, economic, and social affects.

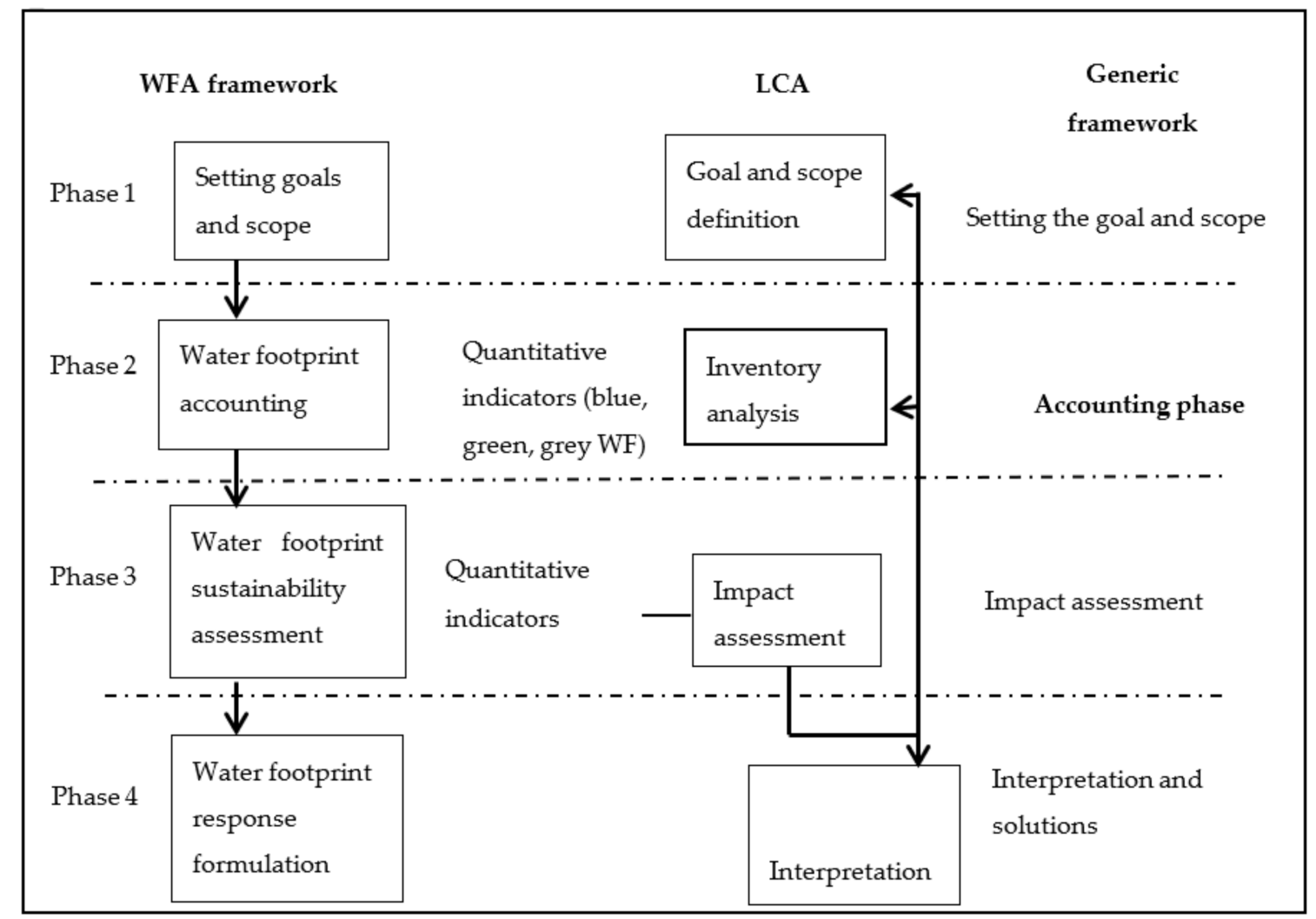

Figure 4. Comparison of LCA and WFA, illustrating the large similarity and the difference in quantitative indicators [61].

\section{Conclusions}

It is evident that South Africa is at risk of water scarcity. All available data indicate that the country is fast approaching physical scarcity. Blue water resources are dry for most months of the year. Agriculture is the major contributor to the current state as this sector uses largely blue water for food production, for both crops and animal products (milk and meat). However, there is little research done to measure the water footprint due to beef production in SA. The country has been shown to be dominated by extensive beef production. There are no studies done to assess water footprint in the extensive system. It can therefore not be concluded that beef production in South Africa plays the largest role in water scarcity problem the country is facing without providing scientific evidence. Extensive beef production also consumes green water, occupying land that is not suitable for any other production. Current and future research activities need to focus on more efficient livestock production methods that reduces water footprint without compromising production. One of the ways to achieve 
reduction of water footprint could be identifying and using breeds that do not require a lot of water per kilogram of meat produced.

Author Contributions: Writing-original draft preparation, A.M.N.; writing-review and editing, M.R.; supervision, B.M. and M.R.; project administration, B.M.; funding acquisition, B.M. and K.N. All authors have read and agreed to the published version of the manuscript.

Funding: This research was funded by Water Research Commission, grant number K5/2964.

Conflicts of Interest: The authors declare no conflict of interest. The funders had no role in the writing of the manuscript or in the decision to publish the results.

\section{References}

1. Mwendera, E.; Atyosi, Y. A review of water storage for socio-economic development in South Africa. J. Water Resour. Prot. 2018, 10, 266-286. [CrossRef]

2. Mpandeli, S.; Naidoo, D.; Mathaudhi, T.; Nhemachena, C.; Nhamo, L.; Liphadzi, S.; Hlahla, S.; Modi, A.T. Climate change adaptation through the water energy food nexus in Southern Africa. Int. J. Environ. Res. Public Health 2018, 15, 2306. [CrossRef] [PubMed]

3. Pelletier, N.; Tyedmers, P. Forecasting potential global environmental costs of livestock production 2000-2050. Proc. Natl. Acad. Sci. USA 2010, 107, 18371-18374. [CrossRef] [PubMed]

4. Sutton, M.A.; Oenema, O.; Erisman, J.W.; Leip, A.; van Grinsven, H.; Winiwarter, W. Too much of a good thing. Nature 2011, 472, 159-161. [CrossRef] [PubMed]

5. Godfray, H.C.J.; Garnett, T.; Jim, W.H.; Timothy, J.K.; Lorimer, J.; Ray, T.P.; Scarborough, P.; Springmann, M.; Jebb, S.A. Meat consumption. Health Environ. Sci. 2018, 361, 5324.

6. Enahoro, D.; D'Croz, D.M.; Mul, M.; Rich, K.M.; Robinson, T.P.; Thornton, P.; Staal, S.S. Supporting sustainable expansion of livestock production in South Asia and Sub-Saharan Africa: Scenario analysis of investment options. Glob. Food Secur. 2019, 20, 114-121. [CrossRef]

7. Porcel, G.C.; Sanchez, D.E.; Alvarez, V.R.; Marin, R.G.; Munoz, D.M. Runoff water as a resource in the Campo de Cartagena (region of Murcia): Current possibilities for use and benefits. Water 2018, 10, 456. [CrossRef]

8. Zuray, R.; Dirar, D. Farmer-led water user association in Agricultural water management. In The Oxford Handbook of Water and Society; Allan, T., Bromwich, B., Keulertz, A.C., Eds.; Oxford University Press: New York, NY, USA, 2019.

9. Adduci, F.; Labella, C.; Musto, M.; D'Adamo, C.; Freschi, P.; Cosentino, C. Use of technical and economical parameters for evaluating dairy cow ration efficiency. Ital. J. Agron. 2015, 10, 202-207. [CrossRef]

10. Zhao, X.; Liao, X.; Chen, B.; Tillotson, M.R.; Guo, W.; Yiping, L.I. Accounting global grey water footprint from both consumption and production perspectives. J. Clean. Prod. 2019, 225, 963-971. [CrossRef]

11. Hoekstra, A.Y.; Chapagain, A.K.; Aldaya, M.M.; Mekonnen, M.M. The Water Footprint Assessment Manual: Setting the Global Standard; Routledge: London, UK, 2011.

12. Chapagain, A.K.; Hoekstra, A.Y. Water Footprint of Nations; UNESCO-IHE: Delft, The Netherlands, 2004; Volume 1.

13. Chapagain, A.K.; Hoekstra, A.Y. The blue, green and grey water footprint of rice from production and consumption perspectives. Ecol. Econ. 2011, 70, 749-758. [CrossRef]

14. Department of Agriculture Forestry and Fisheries. A Profile of the South African Beef Market Value Chain; DAFF: Pretoria, South Africa, 2018.

15. Molden, D. Water for Food, Water for Life: A Comprehensive Assessment of Water Management in Agriculture; Earthscan: London, UK, 2013.

16. Zhuo, L.; Arjen, Y.H.; Wu, P.; Zhao, X. Monthly blue water footprint caps in a river basin to achieve sustainable water consumption: The role of reservoirs. Sci. Total Environ. 2019, 650, 891-899. [CrossRef] [PubMed]

17. Pastor, A.V.; Ludwig, F.; Biemans, H.; Hoff, H.; Kabat, P. Accounting for environmental flow requirements in global water assessments. Hydrol. Earth Syst. Sci. 2013, 10, 14987-15032. [CrossRef]

18. Reimer, J.J. On the economics of virtual water trade. J. Ecol. Econ. 2012, 75, 135-139. [CrossRef]

19. Verlicchi, P.; Grillini, V. Surface water and ground water quality in South Africa and Mozambique-analysis of the most critical pollutants for drinking purposes and challenges in water treatment selection. Water 2020, 12, 305. 
20. Marara, T.; Paramuleni, L.G. A spatiotemporal analysis of water quality characteristics in the Klip river catchment, South Africa. Environ. Monit. Assess 2020, 192, 578. [CrossRef]

21. Mekonnen, M.M.; Hoekstra, A.Y. Four billion people facing severe water scarcity. Sci. Adv. 2016, 2. [CrossRef]

22. Mosase, E.; Ahiablame, L.; Srinivasan, R. Spatial and temporal distribution of blue water in the Limpopo River Basis, Southern Africa: A case study. Ecohydrol. Hygrobiol. 2019, 19, 252-265. [CrossRef]

23. Kummu, M.; Ward, P.J.; de Moel, H.; Varis, O. Is physical water scarcity a new phenomenon? Global assessment of water shortage over the last two millennia. Environ. Res. Lett. 2020, 5. [CrossRef]

24. Porkka, M.; Gerten, D.; Schaphoff, S.; Siebert, S.; Kummu, M. Causes and trends of water scarcity in food production. Environ. Res. Lett. 2016, 11. [CrossRef]

25. Falkenmark, M.; Berntell, A.; Jagerskog, A.; Lundqvist, J.; Matz, M.; Tropp, H. On the Verge of a New Water Scarcity: A Call for Good Governance and Human Ingenuity; Stockholm International Water Institute (SIWI): Stockholm, Sweden, 2007.

26. Rosa, L.; Chiarelli, D.D.; Rulli, M.C.; Dell'Angelo, J.; D'Odorico, P. Global agricultural economic water scarcity. Sci. Adv. 2020, 6. [CrossRef]

27. Pahlow, M.; Snowball, J.; Fraser, G. Water footprint assessment to inform water management and policy making in South Africa. Water SA 2015, 41, 300-313. [CrossRef]

28. Falkenmark, M.; Rockström, J. Balancing Water for Humans and Nature: The New Approach in Ecohydrology; Earthscan: London, UK, 2004.

29. Steinfeld, H.; Gerber, P.; Wassenaar, T.; Castel, V.; Rosales, M.; de Haan, C. Livestock's Long Shadow. Environmental Issues and Options; Food \& Agriculture Organization (FAO): Rome, Italy, 2006.

30. Peden, D. Looking Water and livestock for human development. In Water for Food, Water for Life: A Comprehensive Assessment of Water Management in Agriculture; Molden, D., Ed.; Earthscan: London, UK, 2007.

31. Meissner, H.H.; Scholtz, M.M.; Schonfeldt, H.C. The status, socio-economic and environmental impact, and challenges of livestock agriculture in South Africa. Available online: www.rmrdsa.co.za (accessed on 15 July 2019).

32. Ololade, O.O. Understanding the nexus between energy and water: A basis for human survival in South Africa. Dev. S. Afr. 2018, 35, 194-209. [CrossRef]

33. Arias, R.A.; Mader, T.L. Environmental factors affecting daily water intake on cattle finished in feedlots. J. Anim. Sci. 2011, 89, 245-251. [CrossRef]

34. Ahlberg, C.M.; Allwardt, K.; Broocks, A.; Bruno, K.; McPhillips, L.; Taylor, A.; Krehbiel, C.R.; Calvo-Lorenzo, M.S.; Richards, C.J.; Place, S.E.; et al. Environmental effects on water intake and water intake prediction in growing beef cattle. J. Anim. Sci. 2018, 96, 4368-4384. [CrossRef] [PubMed]

35. Malan, J.C.; Flint, N.; Jackson, A.L.; Irving, A.D.; Swain, D.L. Environmental factors influencing cattle's water consumption at offstream watering points in rangeland beef cattle. J. Liv. Sci. 2020, 231. [CrossRef]

36. U.N. World Population Prospects: The 2012 Revision. Dept. Economic and Social Affairs, Population Division, Population Estimates and Projections Section. 2015. Available online: http://esa.un.org/wpp/. (accessed on 26 July 2019).

37. Sartori, M.; Tarvenini, S.; Consalvo, C. Water Footprint of Italy; Alessi, E., Imperatrice, M., Eds.; WWF: Rome, Italy, 2014.

38. Le Roux, B.; van der Laan, M.; Vahrmeijer, T.; Annandale, J.G.; Keith, L.; Bristow, K.L. Water Footprints of Vegetable Crop Wastage along the Supply Chain in Gauteng, South Africa. Water 2018, 10, 539. [CrossRef]

39. Chouchane, H.; Hoekstra, A.Y.; Krol, M.S.; Mekonnen, M.M. The water footprint of Tunisia from an economic perspective. Ecol. Indic. 2015, 52, 311-319. [CrossRef]

40. Owusu-Sekyere, E.; Scheepers, M.E.; Jordaan, H. Economic water productivities along the dairy value chain in South Africa: Implications for sustainable and economically efficient water-use policies in the dairy industry. J. Ecol. Econ. 2017, 134, 22-28. [CrossRef]

41. Lardy, G.; Stoltenhow, C.; Johnson, R. Livestock and Water; North Dakota State University: Fargo, ND, USA, 2008.

42. Deutsch, L.; Falkenmark, M.; Gordon, L.; Rockström, J.; Folke, C. Water-mediated ecological consequences of intensification and expansion of livestock production. In Livestock in a Changing Landscape; Steinfeld, H., Mooney, H.A., Schneider, F., Neville, L.E., Eds.; Island Press: Washington, DC, USA, 2010; pp. 97-111.

43. Du Toit, C.J.L.; Meissner, H.H.; van Niekerk, W.A. Direct methane and nitrous oxide emissions of South African dairy and beef cattle. S. Afr. J. Anim. Sci. 2013, 43, 320-339. [CrossRef] 
44. Scholtz, M.M.; van Ryssen, J.B.J.; Meissner, H.H.; Laker, M.C. South African perspective on livestock production in relation to greenhouse gasses and water usage. S. Afr. J. Anim. Sci. 2013, 43, 247-254. [CrossRef]

45. SIWI; IFRI; IUCN; IWMI. Let it Reign: The New Water Paradigm for Global Food Security; Final Report to CSD-13; Stockholm International Water Institute: Stockholm, Sweden, 2005.

46. Falkenmark, M.; Rockström, J. The New Blue and Green Water Paradigm: Breaking New Ground for Water Resources Planning and Management. J. Water Resour. Plan. Manag. 2006, 129-132. [CrossRef]

47. Gerber, P.J.; Hristov, A.N.; Henderson, B.; Makkar, H.; Oh, J.; Lee, J.C.; Meinen, R.; Montes, F.; Ott, T.; Firkins, J.; et al. Technical options for the mitigation of direct methane and nitrous oxide emissions from livestock: A review. Animals 2013, 7, 220-234. [CrossRef]

48. Capper, J.L.; Cady, R.A.; Bauman, D.E. The effects of improved performance in the U.S. dairy cattle industry on environmental impacts between 2007 and 2017. J. Anim. Sci. 2020, 98, 1-14. [CrossRef] [PubMed]

49. Vasconcelos, J.T.; Tedeschi, L.O.; Fox, D.G.; Galyean, M.L.; Greene, L.W. Feeding nitrogen and phosphorus in beef cattle feedlot production to mitigate environmental impacts. Prof. Anim. Sci. 2007, 23, 8-17. [CrossRef]

50. Marẻ, F.A.; Jordaan, H. Industrially finished calves: A water footprint profitability paradox. Water 2013, 11, 2565. [CrossRef]

51. Zimmer, D.; Renault, D. Virtual water in food production and global trade: Review of methodological issues and preliminary results. In Virtual Water Trade. Proceedings of the International Expert Meeting on Virtual Water Trade. Value of Water Research Report12, IHE Delft, The Netherlands, 12-13 December 2002; Hoekstra, A.Y., Ed.; IHE: Delft, The Netherlands, 2003; pp. 93-109.

52. Pimentel, D. Techniques for Reducing Pesticides: Environmental and Economic Benefits; John Wiley: Hoboken, NJ, USA, 1997.

53. Pimentel, D. Livestock Production and Energy Use. In Encyclopedia of Energy; Matsumura, R., Ed.; Elsevier: Amsterdam, The Netherlands, 2004; pp. 671-676.

54. Silanikove, N. Effect of heat stress on the welfare of extensively managed domestic ruminants. J. Livest. Prod. Sci. 2000, 67, 1-18. [CrossRef]

55. Khelil-Arfa, H.; Boudon, A.; Maxin, G.; Faverdin, P. Prediction of water intake and excretion flows in Holstein dairy cows under thermoneutral conditions. Animals 2012, 6, 1662-1676. [CrossRef]

56. Meyer, U.; Stahl, W.; Flachowsky, G. Investigations on the water intake of growing bulls. J. Livest. Sci. 2006, 103, 186-191. [CrossRef]

57. NRC. Nutrient Requirement of Beef Cattle, 7th Revised ed.; National Academy Press: Washington, DC, USA, 2000.

58. Cosentino, C.; Adduci, F.; Musto, M.; Paolino, R.; Freschi, P.; Pecora, G.; D'Adamo, C.; Valentini, V. Low vs high "water footprint assessment" diet in milk production: A comparison between triticale and corn silage based diets. Emir. J. Food Agric. 2015, 27, 312-317. [CrossRef]

59. Atzori, A.S.; Canalis, C.; Fransesconi, A.H.D.; Pulina, G. A preliminary study on a new approach to estimate water resource allocation: The net water footprint applied to animal products. Agric. Agric. Sci. Procedia 2016, 8, 50-57. [CrossRef]

60. Vanham, D.; Bidoglio, G. A review on the indicator water footprint for the EU28. Ecol. Indic. 2013, 26, 61-75. [CrossRef]

61. Boulay, A.; Hoekstra, A.Y.; Vionnet, S. Complementaries of water-focused Life Cycle Assessment and Water Footprint Assessment. Environ. Sci. Technol. 2013, 47, 11926-11927. [CrossRef] [PubMed]

62. Pacetti, T.; Lombardi, L.; Federici, G. Water-energy Nexus: A case of biogas production from energy crops evaluated by Water Footprint and Life Cycle Assessment (LCA). J. Clean. Product. 2015, 101, 278-291. [CrossRef]

Publisher's Note: MDPI stays neutral with regard to jurisdictional claims in published maps and institutional affiliations. 